\title{
TOLERANCE DIFFERENCES AND INTERSPECIFIC COMPETITION IN THREE MEMBERS OF THE AMPHIPOD GENUS GAMMARUS
}

\author{
by \\ HENK G. DENNERT \\ Institute of Taxonomic Zoology, University of Amsterdam, The Netherlands
}

\begin{abstract}
In a series of experiments with $G$. pulex, G. duebeni celticus and $G$. duebeni duebeni populations, pure or mixed, their tolerances for several temperature/salinity conditions have been determined. Tested were $100 \%$, $10 \%, 1 \%$ and $0.1 \%$ seawater in combination with temperatures of $5^{\circ}, 10^{\circ}$ or $15^{\circ} \mathrm{C}$. In general all species preferred the $5^{\circ} \mathrm{C}$ conditions above those with a higher temperature, and the middle salinity range $(1 \%$ for $G$. pulex, $1 \%$ and $10 \%$ for $G . d$. celticus and $G . d$. duebeni) above the lower or higher salinities.

In nearly all situations tested $G$. pulex had a lower survival rate than $G$. d. celticus and $G$. d. duebeni.

Notwithstanding the sometimes unfavourable conditions for $G$. pulex, this species can compete successfully with $G$. $d$. celticus under most of the experimental conditions, but the interspecific relations between $G$. pulex and $G$. $d$. duebeni end in the competitive exclusion of the first species. These results support two theories: (1) G. pulex is able to compete successfully with $G$. d. celticus and to expel the latter from its niche, and (2) G.d. duebeni is able to invade freshwater and to establish inuand populations.

The differences demonstrated between $G$. $d$. celticus and $\boldsymbol{G}$. $d$. duebeni are an argument for a different development and different capabilities of both subspecies.

Sterile interspecific matings between $G$. pulex and both subspecies of $G$. duebeni are temperature dependent and do not play a major role in the interspecific relations connected with competition.
\end{abstract}

\section{RESUME}

Au cours d'une série d'expériences avec des populations de G. pulex, G. duebeni celticus et $G$. duebeni duebeni, les tolérances de ces espèces ont été déterminées pour plusieurs combinaisons de température et de salinité, aussi bien d'une seule espèce que de plusieurs espèces mélangées. On s'est servi d'eau de mer pure, et de dilutions de $10 \%, 1 \%$ et $0,1 \%$ en combinaison avec des températures de $5^{\circ} \mathrm{C}, 10^{\circ} \mathrm{C}$ ou $15^{\circ} \mathrm{C}$. En général toutes les espèces ont préféré les conditions de $5^{\circ} \mathrm{C}$ à celles des températures plus élevées et elles ont préféré aussi les salinités moyennes ( $1 \%$ pour $G$. pulex, $1 \%$ et $10 \%$ pour G. $d$. celticus et $G$. d. duebeni) aux salinités plus basses ou plus élevées.

Dans presque toutes les conditions examinées G. pulex avait un degré de survivance plus bas que $G$. d. duebeni et $\boldsymbol{G}$. $d$. celticus.

Malgré les conditions expérimentales parfois défavorables pour $G$. pulex, cette espèce peut concurrencer $G$. $d$. celticus avec succès sous la plupart des conditions expérimentales, mais les relations interspécifiques entre $\boldsymbol{G}$. pulex et $G$. d. duebeni résultent à l'exclusion compétitive de la première espèce. Deux théories sont soutenues par ces résultats: (1) G. pulex est capable de concurrencer $G$. $d$. celticus avec succès et d'expulser le dernier de sa niche, et (2) G. $d$. duebeni est capable d'envahir l'eau douce et d'étabilir des populations dans l'intérieur.

Les différences démontrées entre $G . d$. celticus et $G . d$. duebeni portent à croire que le développement et les capacités des deux sous-espèces sont différents de même.

Les copulations stériles et interspécifiques entre $G$. pulex et les deux sous-espèces de $G$. duebeni dépendent de la température et ne jouent pas un rôle important dans les relations interspécifiques se rapportant à la compétition.

\section{INTRODUCTION}

This paper is mainly concerned with the interspecific competition between Gammarus pulex (Linnaeus, 1758) and Gammarus duebeni Liljeborg. 1852. From the latter, two subspecies have been described by Stock \& Pinkster (1970), viz. G. duebeni duebeni, the brackish water form, and G. duebeni celticus, the freshwater form.

For a better understanding of the problems connected with the competition between these three gammarids, a synopsis of the development of the theories concerning the distribution of $G$. duebeni and $G$. pulex is indispensable.

Based on distribution differences, Reid (1939), followed by Hynes (1954) divided $G$. duebeni into two forms: the form $G$. duebeni $\alpha$, living in fresh water in Ireland, and the typical form $G$. duebeni $\beta$, living in brackish coastal waters, mostly in marginal biotopes such as rockpools. Differences in phys. iology between $G$. duebeni from freshwater biotopes and brackish water biotopes were mentioned 
by Reid (1939) and Hynes (1954, 1955), and thoroughly investigated by Sutcliffe $(1967,1970,1971)$ and Sutcliffe \& Shaw (1968).

Based on these investigations Sutcliffe \& Shaw concluded, that the brackish water form belonged to a physiological race, distinct from the race inhabiting the limnic waterbodies of Eire. Animals occurring in rivers on British peninsulas and on the Isle of Man were assumed to be originally brackish water animals penetrating into the rivers from the coastal waters and estuaries.

Pacaud (1952) stated that also in France, viz. in Normandy and Brittany, G. duebeni occurred in fresh water; this observation was, for Brittany, confirmed by Hynes (1959), who suggested that a detailed survey of the distribution of $G$. duebeni in western France should be carried out. This suggestion was followed by Pinkster et al. (1970).

In contradistinction to Reid (1939), who failed to find morphological differences between the two forms he distinguished, Stock \& Pinkster (1970) and Pinkster et al. (1970) observed slight morphological differences between the brackish and freshwater form. Thus support was given to the evidence resulting from physiological experiments, that the two forms are really distinct. After calculating the coefficient of difference ${ }^{1}$ ) according to Mayr, Linsley \& Usinger (1953), Pinkster et al. (1970) found the two forms different on a subspecific level, and they created the two subspecies mentioned earlier.

There have been three hypotheses on the evolution of the two G. duebeni forms. The first, postulated by Hynes $(1954,1955)$, stated that $G$. duebeni was formerly widespread in fresh waters in western Europe and is now being eliminated from fresh water through competition by $G$. pulex. In Hynes' view, the omnipotent $G$. duebeni is being expelled into brackish waterbodies by the invading G. pulex.

The second hypothesis, developed by Sutcliffe (1967) and based mainly upon the results of his physiological experiments, is the reverse of Hynes' theory: G. duebeni, originally an euryhaline brackish water inhabitant, is colonizing suitable freshwater niches not occupied by $G$. pulex. So, by natural selection of animals with a better than aver-

2) This coefficient is not a forerunner of the $t$ test, as Sutcliffe (1972) supposed, but a mathematical expression of (one of) the definition(s) of a subspecies, viz. that 75\% of population A should be morphologically different from $97 \%$ of population $B$. age sodium regulation mechanism, $G$. duebeni is colonizing an open niche. The absence of $G$. pulex in river systems, partly occupied by $G$. duebeni, is used by Sutcliffe to support his theory. Consequently, interspecific competition between $G$. duebeni and $G$. pulex can be no regulating factor in the distribution of $G$. duebeni.

After reviewing the strong and weak points in both theories, Pinkster et al. (1970) used the zoogeographical data collected in Brittany in connection with the data presented by Hynes $(1954,1955)$ and Sutcliffe (1967), to bring forward a theory about the origin of the two subspecies - a theory not contradicting any piece of evidence available. According to this theory the preglacial $G$. duebeni was a marine cold-temperate species inhabiting the tidal belts of northern Europe and eastern North America. In the interglacial periods some $G$. duebeni populations gradually adapted to freshwater habitats created by the melting ice. Remnants of these populations are now found in Eire, Britanny and some British peninsulas. In this way, the division of the two subspecies could be explained. After the last glacial period, other gammarids could spread from their refugia over' Europe. A microgeographical analysis in Brittany appeared to indicate that $G$. pulex was competing with $G$. $d$. celticus, and was slowly driving the latter in seaward direction. This process is completed in most parts of Europe formerly inhabited by $G$. $d$. celticus, such as England and Normandy, but not yet in the western part of Brittany. G. pulex failed to reach Ireland, so $G$. $d$. celticus remained one of the most abundant inhabitants of the fresh water in Eire.

In the theory of Pinkster et al. (1970) interspecific competition between $G$. $d$. celticus and $G$. pulex plays an important role. Indirect evidence for this competition is found in the zoogeographical analysis: in only 4 out of the 364 stations with $G$. pulex or $G$. $d$. celticus investigated in Brittany, both species occurred together. This means, that most probably the two species are mutually exclusive. This brings us to the issue of the present paper, the interspecific relation between $G$. pulex and both subspecies of $G$. duebeni.

Competition, being one of the important intraspecific and interspecific relations, is discussed by Milne (1961), who summarizes 11 different definitions and meanings of the term competition. Milne concludes that "competition is the endeavour of two (or more) animals to gain the same particular thing, or to gain the measure each wants from the 
supply of a thing when that supply is not sufficient for both (or all)" (Milne, 1961: 57).

Interpreting this definition, Milne makes clear that competition can be both intraspecific and interspecific, and can be so for such different things as mates, food and space; the latter two in the widest sense of the words. Hence competition for space can include the abiotic competition (or conditioning to the medium). A typical predator-preyrelationship between two species cannot be regarded as competition. In this, the biomathematicians Rescigno \& Richardson (1967) agree with Milne (1961), although other authors (Park, 1954; Odum 1971) while defining competition by its results, include a predator-prey relationship in the term competition.

In his study on the competitive exclusion of the crayfish Orconectes immunis by Orconectes virilis, Bovbjerg (1970) mentioned two premises, both applicable to the situation as mentioned earlier for $G$. pulex and $G$. $d$. celticus. The first premise is that a difference must be demonstrated in the level of aggression of the two species, the second premise is that at least one of the biotic and abiotic factors regulating the distribution of the species is short in supply. This factor must be for both species biologically necessary and equally suitable or useful for each of the two species.

As aggressive animals tend to migrate away from areas of high population density (Bovbjerg, 1970; Dennert et al., 1969; Dennert \& van Maren, 1974), this migration constitutes an important intraspecific density regulating mechanism.

In avoiding by means of migration too strong an intraspecific competition, the possibility of interspecific competition is opened in cases where the niches invaded are already occupied by another related species or subspecies.

The question that can be raised in the case of G. pulex invading Brittany is therefore: are there arguments, other than the zoogeographical ones mentioned before, that support the observations of Pinkster et al. (1970), viz. that interspecific competition does exist between $G$. pulex and $G$. $d$. celticus?

In order to find an answer to this question, a series of experiments have been set up in which the survival rates of experimental populations of purely $G$. pulex were compared with the survival rates in situations with $G$. pulex and $G$. d. duebeni or $G$. $d$. celticus mixed in the same aquaria.

Doing so, a suggestion of Miller (1967) was fol- lowed. When discussing the fundamental niche of a species compared with the realized niche, he stated that when competition is supposed to exist between two sympatric species, and one of them is an invader, the removal or experimental addition of one species affects the realized niche of the other species.

In different environments, animals may display different degrees of fitness, without entering into active competition with one another. The outcome of competition will vary therefore not only with the intensity of the competition, but also with the environment in which it takes place.

With regard to aquatic invertebrates, Croghan (1961) made clear, that adaptation to a certain habitat has a decreasing effect on the competitive capabilities of a species. Since Weber \& Spaargaren (1970) concluded that the adaptation of a species to a certain habitat with well defined temperature and salinity conditions is a response to the combined influence of both factors on the animal, it seemed worth while to test the interactions between the (sub)species in a series of different temperature/salinity conditions.

Before considering the possibility of competitive exclusion of $G$. pulex and both $G$. duebeni subspecies, an estimation of the fundamental niche of the three (sub)species in terms of the environmental conditions used in our experiments should be made. For this reason, in chapter IV, the tolerance of the three (sub)species for the environmental conditions tested are determined and the differences between the species discussed.

\section{MATERIAL AND EXPERIMENTAL PROCEDURES}

The experiments were carried out in a temperature controlled room with a $14 \mathrm{~h}$ light $/ 10 \mathrm{~h}$ dark lightregime. The populations were kept in plastic basins of $25 \times 25 \times 10 \mathrm{~cm}$, filled with water of one of the experimental temperatures and salinities (see table I). For shelter small stones or pebbles were added to each basin. Further information on the rearing methods can be found in the papers of Dennert \& van Maren (1974) and Pinkster (1972).

Each basin started with a population of 100 animals, in the control groups 100 animals of one species, in the experimental groups $50 \mathrm{G}$. pulex along with 50 individuals of $G$. d. duebeni or of $G$. $d$. celticus. Most experiments were carried out in duplicate (i.e. two basins of experimental groups 
Table I. Experimental conditions.

Salinity in \% seawater

\begin{tabular}{lccr}
\hline $\left.0.1 \% \%^{3}\right)$ & $18 \mathrm{mg} / 1 \mathrm{Cl}-( \pm 5)$ & $20 \mathrm{mg} / \mathrm{l} \mathrm{Ca}++$ & $5^{\circ} \mathrm{C}, 10^{\circ} \mathrm{C}$ and $15^{\circ} \mathrm{C}$ \\
$1 \%$ & $180 \mathrm{mg} / \mathrm{l} \mathrm{Cl}-( \pm 20)$ & $40 \mathrm{mg} / \mathrm{l} \mathrm{Ca}++$ & $5^{\circ} \mathrm{C}, 10^{\circ} \mathrm{C}$ and $15^{\circ} \mathrm{C}$ \\
$10 \%$ & $1800 \mathrm{mg} / 1 \mathrm{Cl}^{-}( \pm 50)$ & $80 \mathrm{mg} / 1 \mathrm{Ca}++$ & $5^{\circ} \mathrm{C}, 10^{\circ} \mathrm{C}$ and $15^{\circ} \mathrm{C}$ \\
$100 \%$ & $18000 \mathrm{mg} / 1 \mathrm{Cl}^{-}( \pm 500)$ & $340 \mathrm{mg} / \mathrm{l} \mathrm{Ca++}$ & $5^{\circ} \mathrm{C}, 10^{\circ} \mathrm{C}$ and $15^{\circ} \mathrm{C}$ \\
\hline
\end{tabular}

2) In the experimental and control basins temperature was kept constant with fluctuations of less than $0.5^{\circ} \mathrm{C}$.

s) $0.1 \%$ seawater with a raised $\mathrm{Ca}^{++}$content.

and two basins of control groups per experimental condition).

The animals used in the experiments originated from allopatric populations, $G$. pulex from the Hierdense beek, the Netherlands (collected in October and December, 1971 and October 1972), G. $d$. duebeni from Cap Blanc Nez, at the cliff coast of Pas-de-Calais, France (collected in October and December 1971, and October 1972), and $G$. $d$. celticus from a small rivulet near Moulin-du-Châtel, $2 \mathrm{~km}$ S.E. from Plouescat and a small rivulet crossing Road N788, $3 \mathrm{~km} \mathrm{~S}$. from Lesneven, near le Folgoët; both stations in Brittany, France (collected in October 1971, and January and September 1972).

On one occasion a series of experiments was repeated with contiguous allopatric populations of G. pulex and $G$. $d$. celticus originating from a single stream system in Brittany, but the results of these experiments were statistically not different from the experiments with allopatric populations.

After capture, the animals from each locality were kept in the laboratory for 2 to 4 weeks in water from the locality and at a temperature of $5^{\circ} \mathrm{C}$, before being used in the experiments. Mortality under these conditions was negligible. From the stock populations animals were taken at random for the experimental and control groups. A small sample (15 to 20 individuals) was taken together with each group in order to determine the composition (sex ratio and number of precopulations and ovigerous females) of the experimental and control populations.

At fixed intervals, the animals from each basin were counted, on which occasion the number of surviving specimens of each species and the occurrence of precopulations and ovigerous females were recorded.

Although not all experiments started in the same season, differences in physiological state of the animals were taken into account in the mathematical model used to compare the results of the experiments (factor $E$ in the model, see III).

\section{STATISTICAL CONSIDERATIONS}

Models, describing the competition between two species are developed by Volterra (1931), Lotka (1932), Gause (1932, 1934), Park (1954, 1957), Neyman, Park \& Scott (1956), and Park \& Lloyd (1955). These models are mathematically reexamined and improved by Leslie $(1957,1962)$, Leslie \& Gower $(1958,1960)$ and Rescigno \& Richardson (1965, 1967).

These models, however, do not fit in with the situations existing in our experiments, because in these models a positive birthrate for each species is supposed. Although in most of the experimental basins offspring was produced, most of it was eaten by the adults and the remaining juveniles were removed from the experimental basins and reared in isolated aquaria in order to check the vitality of the offspring produced. So, in fact the birthrate in our experiments was artificially kept at the zero level.

Therefore, a model had to be developed for our experiments, in which the survival rates of the species used in the experiments could be compared. A logistic model seemed to be best applicable, but although there was a good fit in most of the experimental populations, in some of them the extrapolations were too unreliable to be used.

Consequently a stochastic model was made, in which the "mean length of life" of the animals in different situations could be compared. "Length of life" is defined here as the real length of life until the last day of an experiment, thereafter all animals are supposed to die within two days. So we start in all basins with 100 animals, and end with none. An exception is made in section IV.1.

With this model the control groups of one species could be compared with the experimental groups of the same species. Furthermore, the differences between control groups of two species, and the differences between control groups of one species in different environmental conditions could be analyzed. 
At the same time, differences within the control and experimental groups of one species, caused by the fact that the experimental and control populations are kept in more than one basin, could be determined.

Since in each problem tackled, the groups of animals compared are living in more than one basin, a two factor hierarchic analysis of variance model was used (cf. Guenther, 1964). One factor represented the groups of animals, the other factor represented the number of species per basin. Thus, the second factor is nested in the first.

The model used is:

$\mathrm{X}_{i j k}=\mu+\alpha_{i}+\beta_{i j}+E_{i j k}$

in which $X_{i j k}$ represents the length of life of the $k$ th animal in basin $j$ from the group $i$.

The model can be interpreted as follows:

$X_{i j k}$ is supposed to consist of the sum of four components:

A fixed general mean $\mu$ computed from the recorded length of lives of one group, a fixed contribution $\alpha_{i}$ representing the fact that the animal concerned is a member of group $i$, a contribution $\beta_{i j}$ representing the effect of the particular basin in which the animal lives, and a random contribution $E_{i j k}$ of the animal concerned itself.

With this model, in which the $\alpha_{i}$ express the differences between groups of animals, and the $\beta_{i j}$ (for fixed $i$ ) express the differences between the basins in group $i$, we have the possibility to draw valid and reliable conclusions from the experiments by comparing the $\alpha_{i}$ - provided that the assumptions which belong to this model hold at least approximately. These assumptions are:

A. The "length of life" distributions within the basins are allowed to differ only with regard to the level, but are principally the same. In particular the variances are all equal.

B. The "length of life" of each individual is independent of the "length of life" of all the others. C. With regard to the tests and the confidence intervals a third assumption is, that all distributions are normal.

The first assumption is more or less fulfilled, because the variances of the populations do not differ too much. Assumption two is logical and is inherent to life. Our results do not meet the third assumption entirely, because (1) the courses of the survival rate curves are not equal and (2) while computing the "length of life" of the individuals in each basin, all animals alive at the end of an experiment are supposed to die two days after the end of the experiment in order to allow a comparison between the survival rate curves. However, the analysis of variance method is passably robust for deviations of normality and may therefore still be used in our case.

It should be noted, that the $\beta_{i j}$ are taken to be fixed constants. Perhaps it should have been more realistic to consider the basins as a random sample from a whole population of basins, in which case they would become random variables. The random effect model, which would be considered in this case, would give less information and the statistical theory of this model is less developed than for the model we have used.

Testing that there are no differences between two or more groups of animals, can be done by testing the $H_{o}$ hypothesis that all $\alpha_{i}$ are zero. Testing that there is no effect caused by the basin in which a population was kept, can be done testing the $H_{o}$ hypothesis that all $\beta_{i j}$ are zero. Both tests are carried out with the standard $F$ test for the analysis of variance. In three of the twenty-four situations, only one group of control animals existed. In these cases the $F$ test is somewhat less reliable, but still can be used. Furthermore, confidence intervals are computed for every pair of $\alpha_{i_{1}}-\alpha_{i_{2}}$ of every species. In this way, significant differences between populations of one species in the various environmental conditions can be determined (see section IV.2).

In all cases where the standard $F$ test for the analysis of variance is used, tables containing the computed values of the variances, the $F$ values and the simultaneous confidence intervals of $\alpha_{i_{1}}-\alpha_{i_{2}}$ are deposited at the Institute of Taxonomic Zoology of the University of Amsterdam.

\section{TOLERANCE OF THE (SUB)SPECIES}

\section{IV.1. Introduction}

In order to find the optimal conditions for each (sub)species out of the 12 conditions tested, the tolerance of each of the species for each experimental condition has been determined.

This is done by estimating the average length of life of each species in each combination of parameters. By means of a two factor hierarchic analysis of variance (see chapter III) is examined whether there are differences between the survival rates in the different conditions for each (sub)species. More sophisticated results could be obtained by us- 
ing a multiple analysis of variance model in which temperature and salinity were considered independently, but the model developed in chapter III gives more or less the same results.

Furthermore a sequence is made with regard to the survival rates in the different combinations of conditions tested for each (sub)species, and the statistical difference between each pair of conditions is determined with the aid of Sheffé multiple confidence comparisons (cf. Guenther, 1964). For these operations the control groups of each (sub)species in every combination of experimental conditions are used.

Because more than $90 \%$ of the G. pulex populations died within one week in $100 \%$ seawater, this situation is not taken into consideration for G. pulex.

As not every experiment lasted the same number of days, all animals were supposed to die on the 51st day of the experiment. Starting from this assumption the average length of life is calculated. Such a rough estimation of the real length of life is not necessarily in agreement with reality, but permits a reliable statistical comparison between the animals of one species under different experimental conditions.

In order to check the reliability of the average length of life values for each experimental condition, the LD 50 values (= the number of days in which $50 \%$ of the original population has died) for each (sub)species are calculated.

Whether the experimental conditions are arranged according to the survival rate they offer to the gammarids tested (expressed in values for the mean length of life), or they are arranged according to the LD 50 value, no or only small and statistically nonsignificant differences occur (see table II).
So we may conclude, that the sequence of the experimental conditions based upon the calculated mean length of life, can be used to determine the optimal conditions for each species expressed in the parameters used in the experiments.

Based on experiments of Lockwood (1961) and Sutcliffe (1968) we can expect that at salinities up to $20 \%$ seawater, $G$. pulex is able to regulate its blood concentration. $G$. $d$. duebeni, which is capable of adapting the concentration of its urine to the outside medium (with isoosmotic urine at an outside salinity of $10,000 \mathrm{mg} / 1 \mathrm{Cl}^{-}$), can withstand a large range of salinities. The sodium uptake mechanism in $G$. $d$. duebeni has, as was shown by Sutcliffe (1968), less affinity for sodium ions than in $G$. $d$. celticus, but $G$. pulex has still a somewhat stronger affinity for sodium ions than $G$. d. celticus.

At temperatures different from the optimum temperature, the tolerance for the salinity factor decreases; so unfavourable salinities are best tolerated at the temperature optimum (Kinne, 1963, 1964).

Hence, based on the field observations of Pinkster et al. (1970), we expect for G. pulex good survival rates at low temperatures and salinities, for $G$. $d$. duebeni good survival rates in brackish water conditions and in a reasonable large range of temperatures, and for $G$. $d$. celticus good survival rates in freshwater and brackish water conditions and low temperature.

\section{IV.2. Results}

The calculated mean length of life (with all control groups pooled) is for $G$. pulex 28.6 days, and for $G$. $d$. duebeni and $G$. $d$. celticus 32.9 and 35.9 days, respectively. In general $G$. pulex has the worst, and $G$. $d$. celticus the best survival rates

Table II. Sequence of the experimental conditions arranged according to the mean length of life (ML) and LD 50 value of each (sub)species.

Decreasing survival rate $\rightarrow$

\begin{tabular}{lllllllllllllll}
\hline G. pulex & ML & 4 & 7 & 2 & 8 & 1 & 5 & 6 & 3 & 9 & & & \\
& LD 50 & 4 & 7 & 2 & 8 & 1 & 5 & 6 & 3 & 9 & & & \\
G.d.celticus & ML & 7 & 4 & 1 & 9 & 8 & 10 & 6 & 3 & 2 & 11 & 5 & 12 \\
& LD 50 & 7 & 4 & 9 & 1 & 8 & 10 & 6 & 11 & 2 & 3 & 5 & 12 \\
G.d.duebeni & ML & 4 & 7 & 11 & 8 & 6 & 1 & 10 & 9 & 2 & 12 & 5 & 3 \\
& LD 50 & 4 & 7 & 11 & 6 & 8 & 10 & 1 & 9 & 12 & 2 & 5 & 3 \\
\hline
\end{tabular}

$1=0.1 \%, 5^{\circ} \mathrm{C} \quad 4=1 \%, 5^{\circ} \mathrm{C}$

$7=10 \%, 5^{\circ} \mathrm{C}$

$10=100 \%, 5^{\circ} \mathrm{C}$

$2=0.1 \%, 10^{\circ} \mathrm{C} \quad 5=1 \%, 10^{\circ} \mathrm{C}$

$8=10 \%, 10^{\circ} \mathrm{C}$

$11=100 \%, 10^{\circ} \mathrm{C}$

$3=0.1 \%, 15^{\circ} \mathrm{C} \quad 6=1 \%, 15^{\circ} \mathrm{C}$

$9=10 \%, 15^{\circ} \mathrm{C}$

$12=100 \%, 15^{\circ} \mathrm{C}$ 


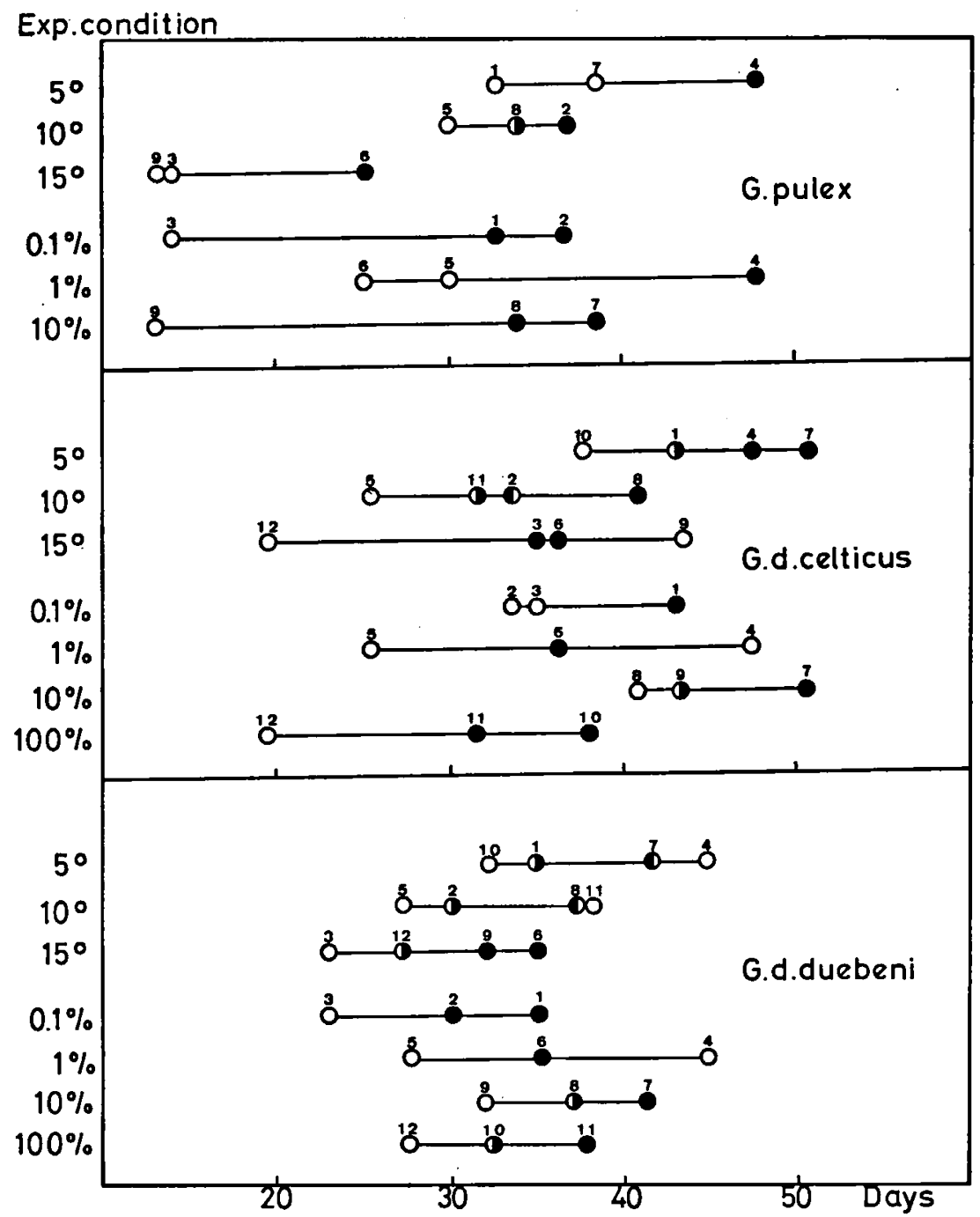

Fig. 1. Survival rate of the three (sub)species in each of the experimental conditions tested. Each dot represents the survival rate in days in one of the temperature/salinity combinations (numbered as in table II) for the three (sub)species tested. The meaning of the nature of the dots (open, half closed, or solid) is as follows: when dot " $x$ " (= the lowest survival rate) is open, and the half of $\operatorname{dot}$ " $x+1$ " or " $x+2$ " facing dot " $x$ " is closed, the difference in survival rate between dot " $x$ " and dot " $x+1$ " or " $x+2$ " is significant at the $5 \%$ level. When the halves of the dots facing each other are of the same nature (both open or both closed), the difference is statistically nonsignificant. As soon as the difference between dot " $x$ " and $\operatorname{dot}$ " $x+1$ " is significant, of course the difference between dot " $x$ " and dot " $x+2$ " and " $x+3$ " is likewise (and even more) significant.

when the results of all experiments are pooled.

From the analysis of variance it became clear, that under different experimental conditions highly significant differences $(P<0.0001)$ exist between the control groups of each species.

In order to get a clear view of the sequence in survival rate in the experimental conditions, the results are segregated for each of the (sub)species and for each temperature and salinity (see fig. 1). It shows, that in all three (sub)species two trends are obvious: 1. At decreasing temperatures survival increases. This is very significantly so for $G$. pulex, in which species all $15^{\circ} \mathrm{C}$ conditions have a lower survival rate than the $10^{\circ} \mathrm{C}$ and $5^{\circ} \mathrm{C}$ conditions. In $G . d$. duebeni and $G . d$. celticus the trend is the same but not significant.

2. In the middle part of the salinity range tested (i.e. $1 \%$ seawater for $G$. pulex and $1 \%$ and $10 \%$ seawater for $G$. $d$. duebeni and $G . d$. celticus) the survival rate is the best. No differences exist in this 
respect between the three (sub)species. For instance at the $1 \%$ seawater conditions the range for $\boldsymbol{G}$. pulex, G. d. duebeni and $G$. $d$. celticus is nearly the same. Some differences occur, however, under suboptimal salinities. At two temperatures the $0.1 \%$ seawater conditions are better for $G$. d. celticus than for $G$. d. duebeni. Generally speaking, for $G . d$. celticus the $0.1 \%$ seawater conditions are better than the $100 \%$ seawater conditions. This sequence is the reverse in the case of $G$. d. duebeni.

\section{IV.3. Conclusions}

In the experiments, the fitness of $G$. pulex was less, compared with the two subspecies of $G$. duebeni. On the average $G$. $d$. celticus had the best survival rates.

The $1 \%$ seawater $5^{\circ} \mathrm{C}$ and the $10 \%$ seawater $5^{\circ} \mathrm{C}$ conditions are the best experimental conditions for all three (sub)species. Under these conditions a strong competition is to be expected. In section VI. 2 this assumption is tested.

The assumption expressed in the introduction to this chapter viz. that temperature is a more important abiotic factor than salinity for the gammarids investigated here, is confirmed.

The differences between $G$. pulex and $G$. d. celticus are great, and especially the small survival chances for $G$. pulex at $15^{\circ} \mathrm{C}$, and the fact that all $G$. pulex die in $100 \%$ seawater within one week, should be mentioned. $G$. $d$. celticus shows to have a wider abiotic range than $G$. $d$. duebeni, with better survival rates at the lowest salinity.

\section{COMPARISON OF THE TOLERANCE OF G. PULEX AND SUBSPECIES OF G. DUEBE- $N I$}

\section{V.1. Introduction}

In a previous section (IV.2) the optimal condi- tions for each of the three (sub)species investigated have been determined. Before discussing the interspecific relationships between these species, the difference in tolerance between $G$. pulex and the two subspecies of $G$. duebeni must be established. From the graphs 1-24 of fig. 2 one can conclude that in most cases $G$. pulex control groups have a lower survival rate than $G . d$. duebeni and $G$. $d$. celticus. In a two factor hierarchic analysis of variance (see chapter III) this phenomenon is further investigated.

\section{V.2. Results}

The results of the analysis of variance are summarized in table III. From this table it can be derived that only in $0.1 \%$ seawater $10^{\circ} \mathrm{C} \mathrm{G}$. pulex control groups have a better survival rate curve than G. $d$. celticus and in $1 \%$ seawater $5^{\circ} \mathrm{C}$ no differences between the two species exist. At $0.1 \%$ seawater $5^{\circ} \mathrm{C}$ and $1 \%$ seawater $10^{\circ} \mathrm{C}$ no differences between $G$. pulex and $G$. d. duebeni are demonstrated, and only at $0.1 \%$ seawater $10^{\circ} \mathrm{C} \mathrm{G}$. pulex survival rate curves of the control groups are significantly better than those of $G . d$. duebeni $(\mathrm{P}<0.01)$.

\section{V.3. Conclusion}

In this section a second argument for a weaker position of $G$. pulex, as compared with $G$. d. celticus and $G$. $d$. duebeni in experimental conditions with high temperature and high salinity, is brought forward.

However, in the next chapter (VI) will be shown that although high temperature conditions are not optimal for $G$. pulex, the stress on the subspecies of $G$. duebeni in these conditions can be still greater, hence $G$. pulex can compete successfully with them.

Table III. Comparison of control groups of G. pulex and G.d.duebeni or G.d. celticus in the same experimental conditions. Statistically significant differences are indicated with $++(P<0.01)$ and $+(P<0.05)$. The place of the plus sign marks the best survival rate curves. Bold type in dicates the conditions in which no difference exists between G. pulex and both subspecies of G. duebeni, or G. pulex has a higher survival rate than both subspecies of $G$. duebeni.

\begin{tabular}{|c|c|c|c|c|c|c|c|c|c|c|c|}
\hline $\begin{array}{l}\text { Environmental } \\
\text { conditions }\end{array}$ & $\begin{array}{c}0.1 \% \\
5^{\circ}\end{array}$ & $\begin{array}{c}0.1 \% \\
10^{\circ}\end{array}$ & $\begin{array}{c}0.1 \% \\
15^{\circ}\end{array}$ & $\begin{array}{c}1 \% \\
5^{\circ}\end{array}$ & $\begin{array}{l}1 \%, \\
10^{\circ}\end{array}$ & $\begin{array}{l}1 \%, \\
15^{\circ}\end{array}$ & $\begin{array}{c}10 \% \\
5^{\circ}\end{array}$ & $\begin{array}{l}10 \%, \\
10^{\circ}\end{array}$ & $\begin{array}{l}10 \%, \\
15^{\circ}\end{array}$ & $\begin{array}{c}100 \% \\
5^{\circ}\end{array}$ & $\begin{array}{l}100 \% \text {, } \\
15^{\circ}\end{array}$ \\
\hline G. pulex & - & + & - & - & - & - & - & - & - & - & - \\
\hline G. d. celticus & ++ & - & $+t$ & - & ++ & ++ & ++ & ++ & ++ & ++ & ++ \\
\hline G. pulex & - & ++ & - & - & - & - & - & - & - & - & - \\
\hline G.d. duebeni & - & - & $+t$ & ++ & - & ++ & ++ & + & ++ & ++ & ++ \\
\hline
\end{tabular}


VI. INTERSPECIFIC RELATIONSHIPS BETWEEN G. PULEX AND THE SUBSPECIES OF G. DUEBENI

\section{VI.1. Introduction}

In chapters IV and V the differences in survival rates of the three (sub)species and the differences within one species with regard to the temperature/ salinity conditions used in our experiments, have been shown.

To examine the influence of one species upon the other, again a two factor hierarchic analysis of variance is used, which makes it possible to determine differences between the control groups (unmixed) and the experimental groups (mixed with another species) of each species under each condition.
When investigating the interspecific relationships between species, we have three possibilities:

(1) Control groups and experimental groups of both species do not differ from each other.

(2) Control groups and experimental groups of one species do not differ, but in the same basins a difference between the two groups of the other species does exist.

(3) Control groups and experimental groups of both species differ from each other; one species is doing better in the experimental groups as compared with the control groups, and one species is doing worse in the experimental groups as compared with the control groups.

In the last two cases we are recording something which is the result of competition or a predatorprey relationship, and in both cases one species is

Table IV. Differences between control groups and experimental groups of G. pulex, G. d. celticus and G. d. duebeni. Statistical significant differences are indicated by $++(P<0.01)$ and $+(P<0.05)$. Nonsignificant differences $(P>0.05)$ are indicated by a 0 . The symbol $>$ expresses a better survival rate of the experimental groups than in the control groups. The symbol < expresses a worse survival rate of the experimental groups than in the control groups.

\begin{tabular}{|c|c|c|c|c|c|c|c|c|c|c|c|}
\hline $\begin{array}{l}\text { Environmental } \\
\text { conditions }\end{array}$ & $\begin{array}{c}0.1 \% \\
5^{\circ}\end{array}$ & $\begin{array}{c}0.1 \% \\
10^{\circ}\end{array}$ & $\begin{array}{c}0.1 \% \\
15^{\circ}\end{array}$ & $\begin{array}{c}1 \% \\
5^{\circ}\end{array}$ & $\begin{array}{l}1 \% \\
10^{\circ}\end{array}$ & $\begin{array}{l}1 \% \\
15^{\circ}\end{array}$ & $\begin{array}{c}10 \% \\
5^{\circ}\end{array}$ & $\begin{array}{c}10 \% \\
10^{\circ}\end{array}$ & $\begin{array}{c}10 \% \\
15^{\circ}\end{array}$ & $\begin{array}{c}100 \% \\
5^{\circ}\end{array}$ & $\begin{array}{c}100 \% \\
15^{\circ}\end{array}$ \\
\hline $\begin{array}{l}G . \text { pulex in combination } \\
\text { with } G, d \text {. celticus } \\
\text { Differences between } \\
\text { control groups and } \\
\text { experimental groups }\end{array}$ & 0 & 0 & 0 & 0 & $t+<$ & $++>$ & $++>$ & 0 & $++>$ & 0 & 0 \\
\hline $\begin{array}{l}\text { Differences within } \\
\text { the control and } \\
\text { experimental groups }\end{array}$ & 0 & 0 & ++ & 0 & 0 & 0 & ++ & 0 & 0 & 0 & 0 \\
\hline $\begin{array}{l}G . d \text {. celticus in combina- } \\
\text { tion with } G \text {. pulex } \\
\text { Differences between } \\
\text { control groups and } \\
\text { experimental groups }\end{array}$ & $++<$ & 0 & $++<$ & $++<$ & $++>$ & $+t<$ & $+t<$ & 0 & $++<$ & 0 & 0 \\
\hline $\begin{array}{l}\text { Differences within } \\
\text { the control and } \\
\text { experimental groups }\end{array}$ & + & 0 & ++ & + & ++ & + & ++ & 0 & 0 & 0 & 0 \\
\hline $\begin{array}{l}\text { G. pulex in combination } \\
\text { with } G . d \text {. duebeni } \\
\text { Differences between } \\
\text { control groups and } \\
\text { experimental groups }\end{array}$ & 0 & $++<$ & 0 & $++<$ & $+t<$ & 0 & $++<$ & $++<$ & $t<$ & $+<$ & 0 \\
\hline $\begin{array}{l}\text { Differences within } \\
\text { the control and } \\
\text { experimental groups }\end{array}$ & 0 & 0 & ++ & ++ & 0 & 0 & + & 0 & + & 0 & 0 \\
\hline $\begin{array}{l}G . d \text {. duebeni in combi- } \\
\text { nation with } G \text {. pulex } \\
\text { Differences between } \\
\text { control groups and } \\
\text { experimental groups }\end{array}$ & 0 & 0 & $+t<$ & $++>$ & 0 & 0 & 0 & $++>$ & 0 & 0 & $+>$ \\
\hline $\begin{array}{l}\text { Differences within } \\
\text { the control and } \\
\text { experimental groups }\end{array}$ & ++ & 0 & ++ & + & 0 & ++ & 0 & 0 & ++ & 0 & 0 \\
\hline
\end{tabular}



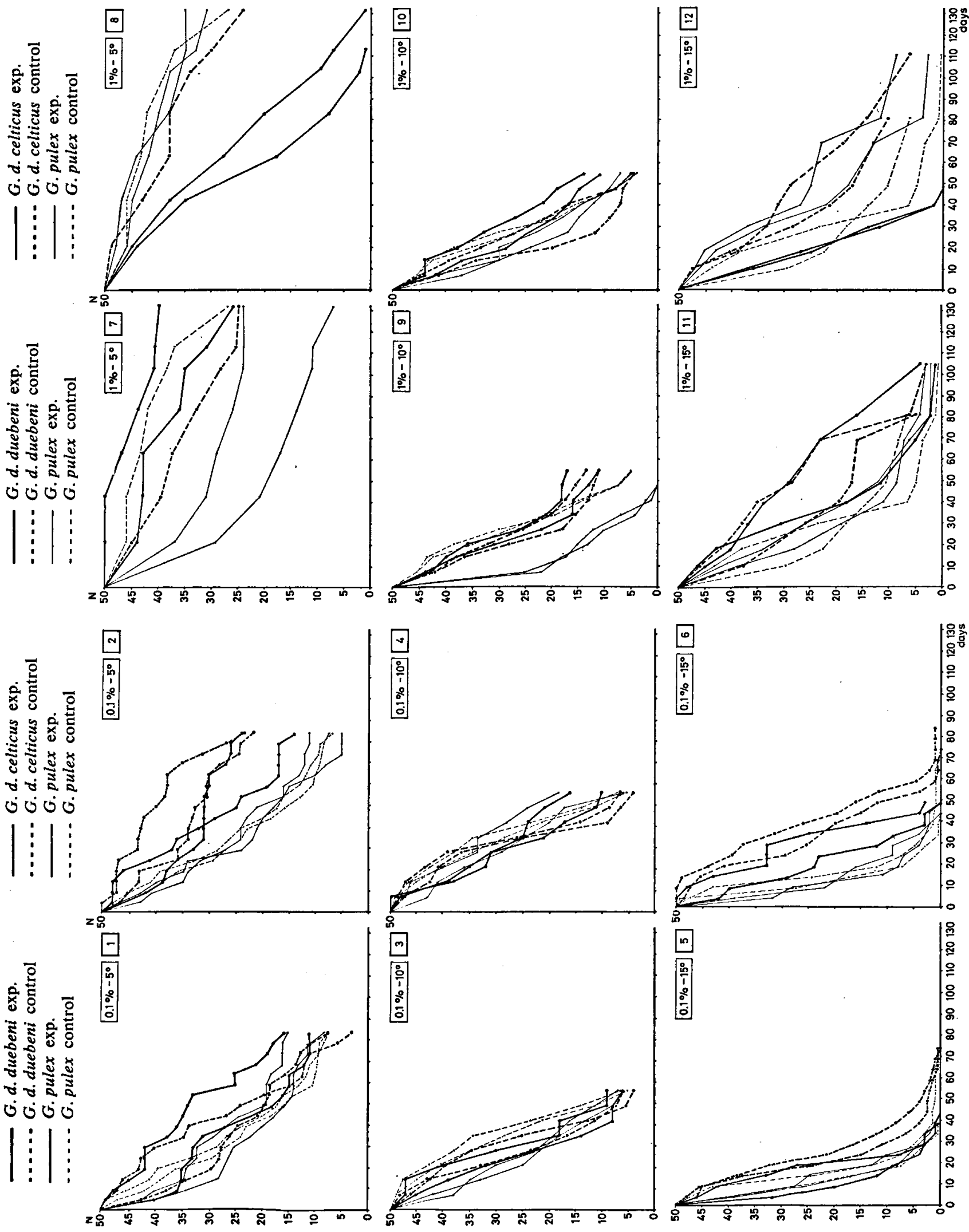

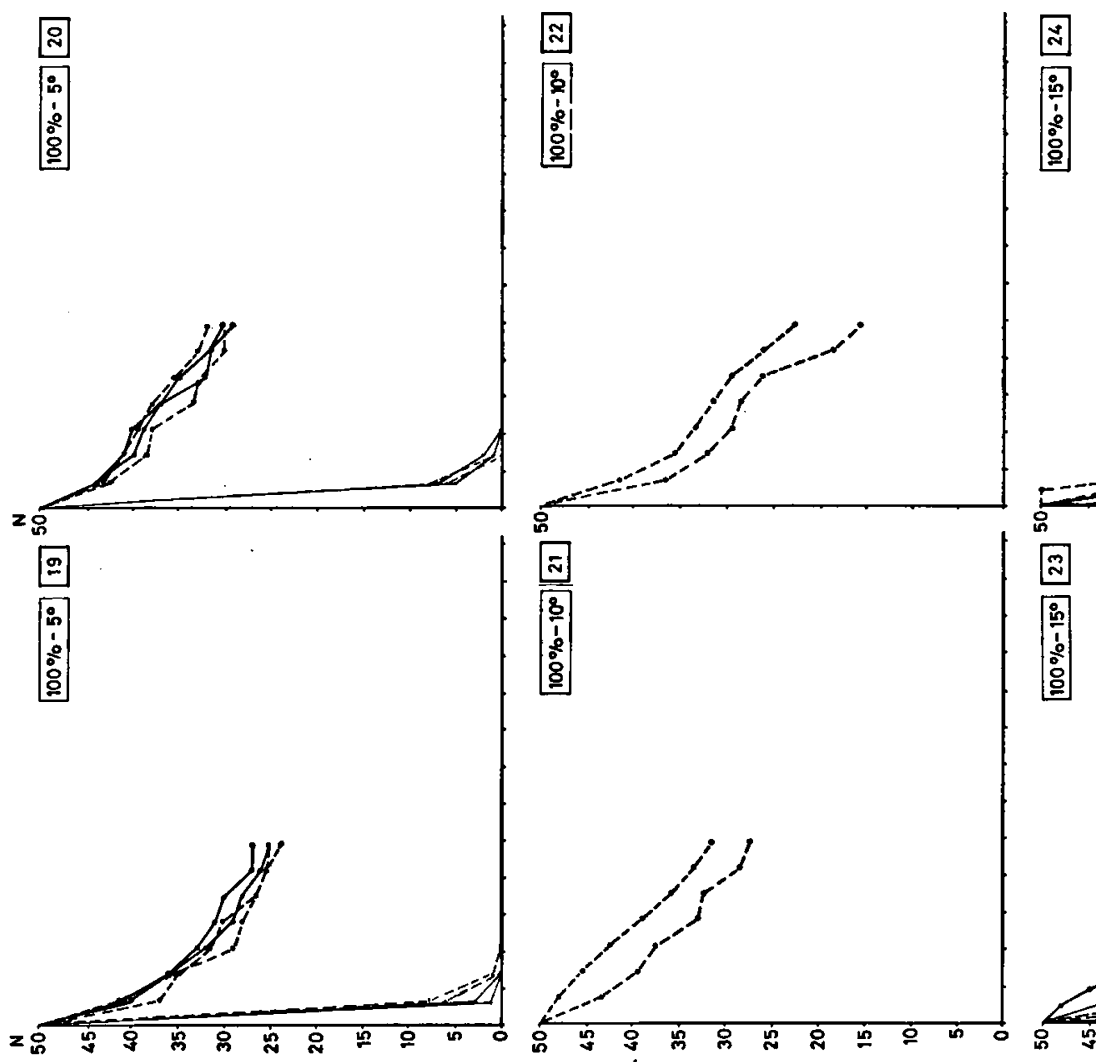

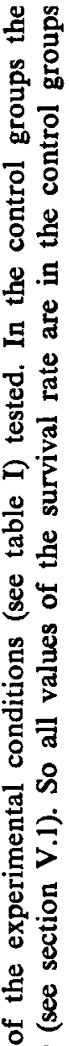
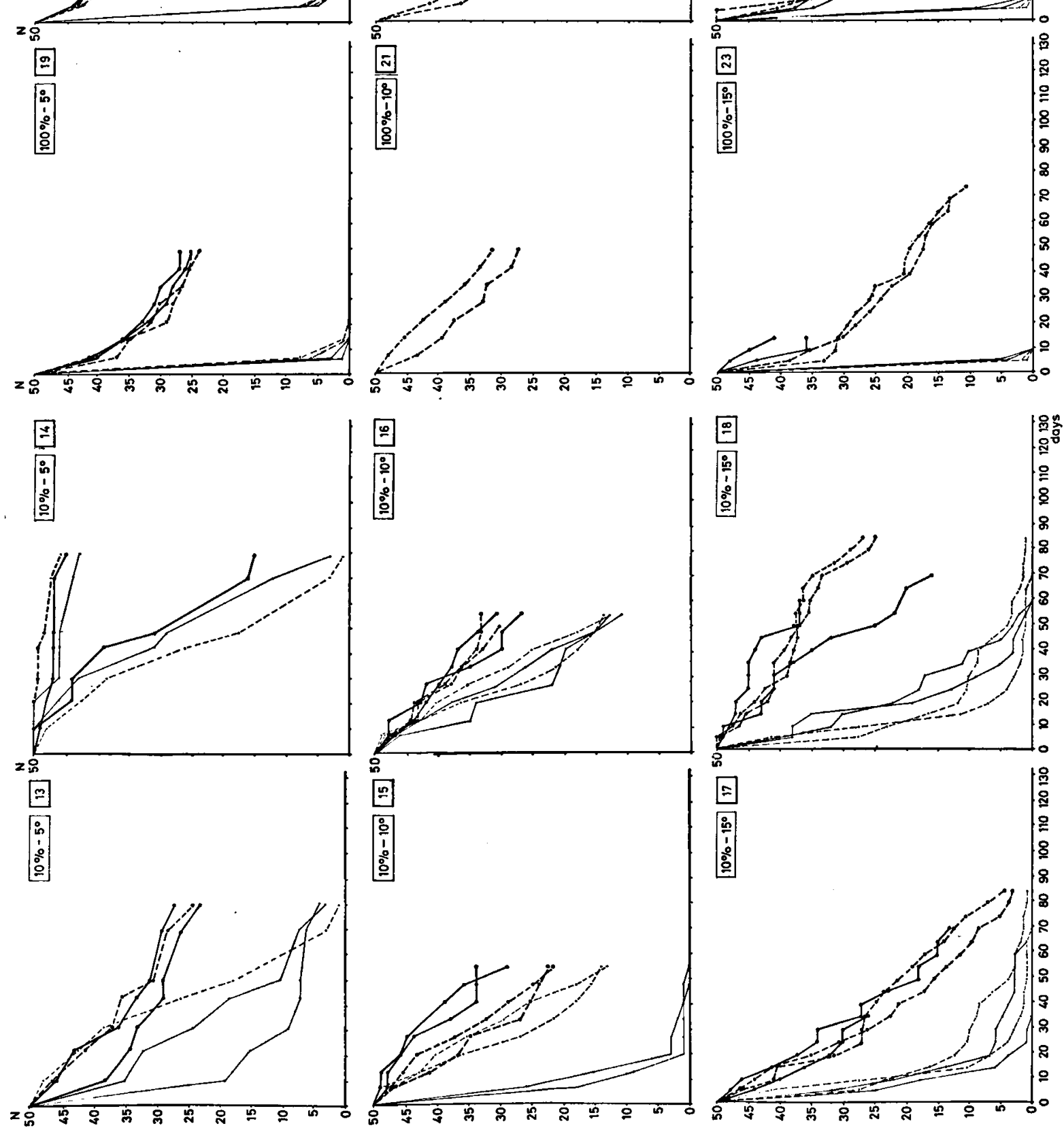

둥

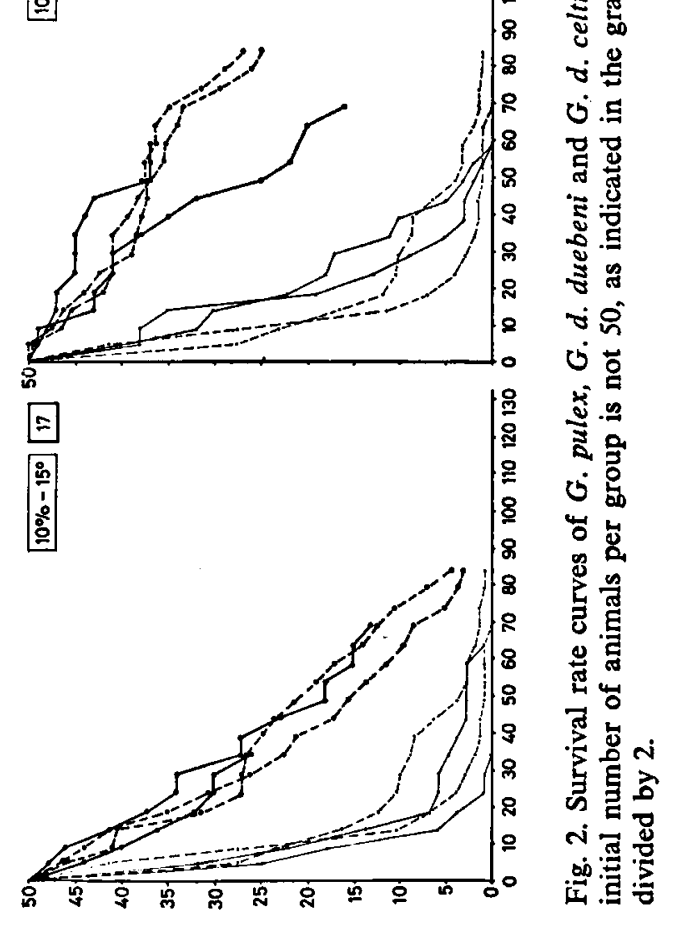


disadvantaged by the presence of the other. An absolute disadvantage occurs, when the presence of one species has a decreasing effect on the survival rate of the other. A relative disadvantage occurs, when the presence of one species has no decreasing effect on the survival rate of the other species, but the first species gets a better survival rate compared with the control groups of its own species.

In the analysis of variance not only the treatment effect, but also the differences between the two control groups and between the two experimental groups of each species are examined.

\section{VI.2. Results}

The fundamental data about the interactions between $G$. pulex and G.d. celticus or G. d. duebe$n i$ are shown in fig. 2,1-24, which displays the survival rates of the three (sub)species in the investigated conditions. Table IV contains the results of the analysis of variance. Note, that although significant differences between the two control groups of one species may exist, this does not prevent a statistical comparison between two species.

At the lowest salinities (fig. 2, 1-6) a negative effect of $G$. $d$. duebeni on the mortality of $G$. pulex is clearly shown, an exception being the $15^{\circ} \mathrm{C}$ condition. $G$. pulex is not negatively influenced by $G$. $d$. celticus, on the contrary, G. $d$. celticus is not doing too well in combination with $G$. pulex.

A closer examination of the data of these experiments shows what happens when two species are competing for the same niche. At $0.1 \%$ seawater $5^{\circ} \mathrm{C}$, no statistical significant influence (cf. table IV) of G. d. duebeni on G. pulex could be found. The influence of G. pulex on G. d. celticus, however, was highly significant. At the $0.1 \%$ seawater $10^{\circ} \mathrm{C}$ condition, $G$. d. duebeni was not influenced in its survival rate, but had a depressing effect on the survival of G. pulex. This condition is also one of the rare conditions tested, in which $G$. pulex had no exterminating effect on $G$. $d$. celticus. The significantly negative effect of $G$. pulex on both subspecies of $G$. duebeni in the $0.1 \%$ seawater $15^{\circ} \mathrm{C}$ condition is clear.

Fig. 2, 7-12 (1\% seawater) shows much the same situation as at $0.1 \%$ seawater (fig. 2, 1-6), with the exception that the effect of $\boldsymbol{G}$. $d$. duebeni on $\boldsymbol{G}$. pulex is more pronounced than at the $0.1 \%$ level. Moreover, at $1 \%$ seawater $10^{\circ} \mathrm{C} \mathrm{G}$. d. celticus can successfully withstand the competition of $G$. pulex.

The third set of graphs (fig. 2, 13-18) shows the $10 \%$ seawater situation; the same trends are visible. Differences are (1) the fact that at $10 \%$ seawater $10^{\circ} \mathrm{C} \mathrm{G}$. d. celticus has a better survival rate, but is no longer advantaged by the presence of $G$. pulex, and (2) the still growing negative effect of $G . d$. duebeni on $G$. pulex.

Note the steeper declination of the mortality rates of $G$. pulex in this series with a higher salinity. The better osmoregulatory performances of both G. d. duebeni and G. d. celticus in comparison with G. pulex are clearly illustrated by the great gap between the mortality curves of $\boldsymbol{G}$. duebeni and G. pulex (see also section V.2). At $0.1 \%$ and $1.0 \%$ seawater this gap existed as well but it was less pronounced.

In the conditions with the highest salinities, viz. $100 \%$ seawater (fig. $2,19-24$ ) G. pulex is doing so poor, that no valid conclusions about the mutual influences of the species can be drawn. To save experimental animals, no experimental or control groups of $G$. pulex were used in the $100 \%$ seawater $10^{\circ} \mathrm{C}$ condition.

In fig. 3 the ultimate (statistically significant) results are summarized. For reasons mentioned above the $100 \%$ seawater conditions are omitted. In this matrix of conditions, those marked with squares represent the situations in which $G$. pulex has a negative effect on the survival of one of the $G$. duebeni subspecies, or is advantaged itself by the presence of $G$. duebeni. In the hatched blocks either $G . d$. duebeni or $G . d$. celticus is dominant.
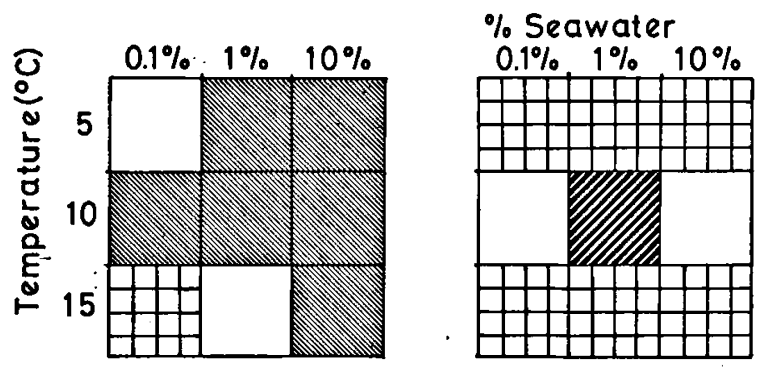

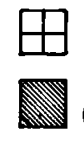

G. pulex

G.d.duebeni

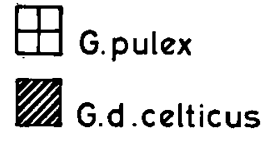

no interference

Fig. 3. Matrix of temperature/salinity combinations in which the dominance of the three (sub)species is indicated. The $100 \%$ seawater conditions are not considered in this matrix (see section VI.2.). 


\section{VI.3. Conclusions}

From the data presented here the conclusion is justified that $G$. pulex can compete successfully with $G$. $d$. celticus in most of the environmental conditions used in our experiments. Only at $10^{\circ} \mathrm{C}$ $G$. $d$. celticus can withstand the competition of $G$. pulex.

On the other hand, $G$. pulex is no match for $G$. d. duebeni. In $0.1 \%$ seawater, the advantage for $G$. $d$. duebeni is limited to the $10^{\circ} \mathrm{C}$ condition, and in all the $10 \%$ seawater conditions $G$. d. duebeni competes successfully with $G$. pulex.

\section{INTERSPECIFIC PRECOPULATIONS}

\section{VII.1. Introduction}

Kinne (1954) mentioned the possibility, that competition for mates may play an important role in the competition between Gammarus species, and may therefore influence their distribution. In general, Milne (1961) agreed with this point of view.

When males from one species mate with the females of another species, the latter is disadvantaged. Since a female must be fertilized immediately after the moult, a female in interspecific precopulation is lost for propagation during one oviposition, it can either produce unfertilized eggs, or sterile eggs.

During our experiments homogamous as well as heterogamous precopulations could be formed freely. Both kind of precopulations were recorded during the experiments to see if the interspecific precopulations play a role in the competition between these particular three (sub)species.

Table V. Accumulated number of homogamous precopula tions (p.c.), heterogamous precopulations, and of heterogamous precopulations as a percentage of the accumulated number of homogamous precopulations recorded in the first 60 days of the experiments in the basins with experimental populations. Recording interval 5 days (or converted into 5 days) and classified according to the experimental salinities and temperatures. Significance levels expressed by +++ or ++ are highly significant $(\mathrm{P}<0.001$ and $\mathrm{P}<0.01$ respectively), expressed by + are significant $(\mathrm{P}<$ $0.05)$, and by 0 nonsignificant $(P>0.05)$.

\begin{tabular}{|c|c|c|c|c|c|c|c|}
\hline & \multicolumn{3}{|c|}{$\%$ Seawater } & \multicolumn{3}{|c|}{ Temperature } & \multirow{2}{*}{$\begin{array}{l}\text { Total } \\
\text { p.c. }\end{array}$} \\
\hline & $0.1 \%$ & $1 \%$ & $10 \%$ & $5^{\circ} \mathrm{C}$ & $10^{\circ} \mathrm{C}$ & $15^{\circ} \mathrm{C}$ & \\
\hline of G. pulex $\times$ \& G. pulex & 78 & 193 & 47 & 171 & 32 & 115 & 318 \\
\hline o G.d. celticus $\times$ o G.d. celticus & 121 & 61 & 200 & 164 & 114 & 104 & 382 \\
\hline o G. pulex $\times \uparrow$ G.d. celticus & 28 & 19 & 5 & 26 & 20 & 6 & 52 \\
\hline o G.d. celticus $\times \&$ G. pulex & 3 & 4 & 49 & 46 & 5 & 5 & 56 \\
\hline
\end{tabular}

A. $f$ G. pulex $\times \%$ G.d. celticus as a $\%$ of the homogamous $G$. pulex p.c.

B. of G.d. celticus $\times \circ G$. pulex as a $\%$ of the homogamous $G$. $d$. celticus p.c.

$\begin{array}{llllll}39 & 10 & 11 & 15 & 63 & 6\end{array}$

Significance level of the difference between A and B

C. $\&$ G. pulex $\times \%$ G.d. celticus as a $\%$ of the homogamous $G$. $d$. celticus p.c.

D. of G.d.celticus $\times \$$ G. pulex as a $\%$ of the homogamous $G$. pulex p.c.

Significance level of the difference between $\mathbf{C}$ and $\mathbf{D}$

f G. pulex $\times$ ㅇ G. pulex

ô G.d.duebeni $\times \$$ G.d.duebeni

of G. pulex $\times$ \% G.d.duebeni

o G.d.duebeni $\times$ ㅇ G. pulex

$\begin{array}{lllll}2 & 7 & 25 & 28 & 4\end{array}$

E. $\delta$ G. pulex $\times$ \% G.d.duebeni as a \% of the homogamous $G$. pulex p.c.

F. $\hat{o}$ G.d.duebeni $\times$ \& G. pulex as a $\%$ of the homogamous $G$. $d$. duebeni p.c. Significance level of the difference between $\mathbf{E}$ and $\mathbf{F}$

G. $\delta$ G. pulex $\times \%$ G.d.duebeni as a \% of the homogamous $G$. d. duebeni p.c.

H. $\delta$ G.d.duebeni $\times \$$ G. pulex as a $\%$ of the homogamous $G$. pulex p.c.

Significance level of the difference between $\mathbf{G}$ and $\mathbf{H}$

$\begin{array}{lllllll}23 & 31 & 3 & 16 & 17 & 6 & \\ 4 & 2 & 104 & 27 & 16 & 4 & \\ +++ & +++ & +++ & 0 & 0 & 0 & \\ 97 & 100 & 39 & 126 & 24 & 86 & 236 \\ 35 & 114 & 106 & 144 & 60 & 51 & 255 \\ 5 & 21 & 2 & 14 & 0 & 14 & 28 \\ 1 & 7 & 55 & 59 & 1 & 3 & 63 \\ 5 & 21 & 5 & 11 & 0 & 16 & \\ 3 & 6 & 52 & 41 & 2 & 6 & \\ 0 & ++ & +++ & +++ & 0 & + & \\ 14 & 18 & 2 & 10 & 0 & 27 \\ 1 & 7 & 141 & 47 & 4 & 3 \\ +++ & + & +++ & +++ & + & +++\end{array}$


Table VI. Significant differences between the heterogamous precopulations of two species. When dots are present, the precopulation concerned occurs significantly more often than the reciprocal precopulation. Open and solid dots represent differences between the heterogamous precopulations, which are expressed as percentages of the homogamous precopulations of the males and females, respectively.

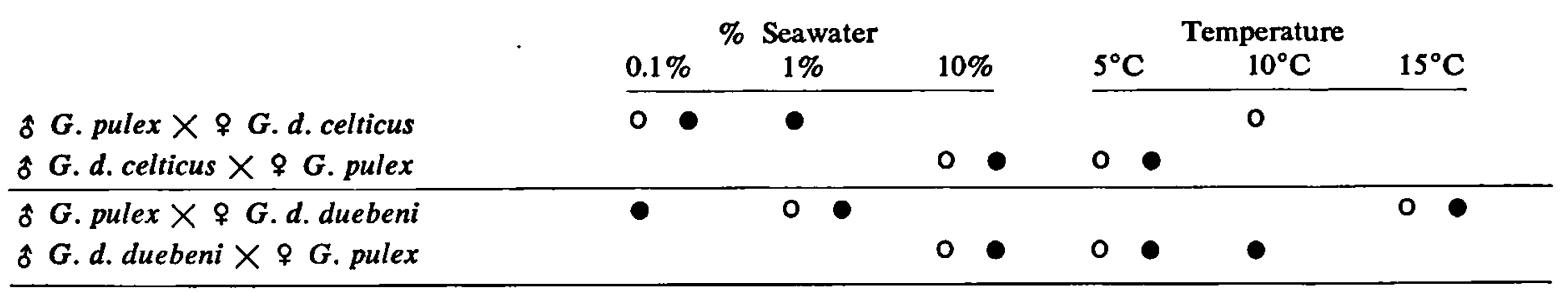

\section{VII.2. Results}

Table $\mathrm{V}$ contains the accumulated numbers of homogamous and heterogamous precopulations recorded during the experiments. As the mating frequency, due to differences in season and composition of the populations used, differed between the experimental populations, the heterogamous precopulations are expressed in table $\mathrm{V}$ as percentages of the homogamous precopulations of both species concerned. As is to be seen from table V, the total number of homogamous precopulations in the experimental groups does not vary very much, whereas significant differences exist between the percentages of the heterogamous precopulations (tested with the $\chi^{2}$ test).

Table VI contains a synopsis of the significant differences between the heterogamous precopulations expressed as percentages of the homogamous precopulations. From table VI it follows that: (1) At low salinities a significant tendency is that $G$. pulex males take more $G$. $d$. celticus and $G$. $d$. duebeni mates than the males of the latter two take G. pulex mates. At high salinity ( $10 \%$ seawater) the reverse occurs and more $G$. $d$. celticus and $G$. $d$. duebeni males mate with $G$. pulex females than G. pulex males mate with $G$. d. celticus or $G . d$. duebeni females. (2) When classified with regard to the temperature, at $5^{\circ} \mathrm{C}$ both $G$.d.duebeni and G. $d$. celticus males mate more frequently with $G$. pulex females than in the reciprocal precopulations G. pulex males mate with $G$.duebeni females. At $15^{\circ} \mathrm{C} G$. pulex males mate with $G$. $d$. duebeni females significantly more often than vice versa, whereas the two reciprocal matings possible between G. pulex and G.d.celticus do not differ significantly.

\section{VII.3. Conclusions}

No correlation exists between the data present- ed in chapter VII and those of the previous chapter VI. Hence we may conclude, that no correlation exists between the dominance of the species and the occurrence of interspecific precopulations.

No correlation can be proved between the percentages of heterogamous precopulations and the optimal conditions for the (sub)species (see chapter IV).

The only conclusion justified is, that when $G$. pulex is in a suitable experimental condition, the males mate more frequently with $G$. duebeni females, than that the reverse would happen. So, in the case of $G$. pulex competing with $G$. d. celticus at low salinities and high temperatures, the interspecific precopulations are in the favour of $G$. pulex.

\section{DISCUSSION AND CONCLUSION}

In the introduction of this paper, three theories concerning the distribution of $G$. pulex and $G$. duebeni in Brittany are mentioned. The goal of the present investigation was to find evidence for the explanation by Pinkster et al. (1970) of the distribution pattern of both species in Brittany. According to this theory, competitive exclusion would play a major role in the process in which the invader $G$. pulex exterminates the original inhabitant of the fresh waters of Brittany, G. $d$. celticus.

What evidence have we established in this paper?

A) Our survival experiments have shown (see chapter V), that compared with $G$. d. celticus and G. d. duebeni, G. pulex was less able to withstand a wide range of experimental salinity/temperature combinations. Many of the conditions used in the experiments, are similar to the limnic conditions found in nature at localities with $G$. pulex. Under certain limnic conditions (see table III), G. pulex may have a fitness equal to or even better than 
G. d. celticus or $\boldsymbol{G}$. d. duebeni. With increasing temperature and salinity the fitness of $G$. pulex decreases very rapidly.

A ranking of the environmental conditions, according to the survival rate, revealed that not only in the conditions mentioned above, but also in conditions with a relatively high salinity $(10 \%$ seawater) and low temperatures $\left(5^{\circ}\right.$ and $\left.10^{\circ} \mathrm{C}\right) \mathrm{G}$. pulex has a less than average mortality (see chapter IV). For $G$. pulex therefore, the fitness to compete with $G$. duebeni can not be linked too strictly to the environmental conditions.

For most of the conditions tested, $G$. $d$. celticus and $G$. $d$. duebeni have a better tolerance than G. pulex. Remarkable is that all three (sub)species have the best survival rate in the same two conditions $\left(1 \%\right.$ seawater $5^{\circ} \mathrm{C}$ and $10 \%$ seawater $5^{\circ} \mathrm{C}$ ).

B) Interspecific interactions are clearly demonstrated in chapter VI. Although the theoretical question can be raised, whether these interactions are based purely on competition, or on a mixture of competition and predation, it can be said (in agreement with Miller, 1967) that competitive exclusion of one species by another is the result of some of these interactions. The conclusion seems to be justified (see fig. 3) that G. pulex is able to compete successfully with G.d.celticus, but is unable to compete with $G$. $d$. duebeni in most environmental conditions.

The evidence about the fitness of the three (sub)species discussed in A, shows no consistent agreement with the results of the interaction analysis discussed here. Analysis of the relations between $G$. pulex and $G$. $d$. duebeni, for instance, reveals that $G$. pulex is not able to compete with $G$. $d$. duebeni, even in those conditions most favourable for the first species. On the other hand, G. pulex can compete successfully with $G$. $d$. celticus, not only under optimal conditions, but also in far less favourable situations.

C) The occurrence of interspecific precopulations may play a role in the competition between the species, but the formation of these precopulations shows to be more temperature dependent than related to the dominance of one species in a certain environment (see chapter VII). In certain situations, however, the effect of sterile interspecific mating accumulates on top of the effect of other competitive interactions. This is illustrated by the large number of interspecific precopulations between male $G$. $d$. duebeni or $G$. d. celticus, and female G. pulex at high salinities (see table V). G. d. duebeni, already favoured by these conditions, gets an extra advantage through interspecific mating. On the other hand, $G$. $d$. celticus is able to avoid to a certain extent the competitive stress caused by $G$. pulex through this advantageous interspecific mating.

The conclusions to be drawn from the evidence presented above are:

- As to the distribution of $G$. $d$. celticus and $G$. pulex we must agree with Pinkster et al. (1970), that $G$. pulex is capable of expelling $G$. d. celticus from the limnic waters of Brittany.

Since in Brittany in most of the rivers and rivulets inhabited by $G$. $d$. celticus, temperatures vary between $8^{\circ} \mathrm{C}$ and $20^{\circ} \mathrm{C}$, whereas salinities corresponding with 0.1 to $0.5 \%$ seawater are usual, one may say, that introduction of $G$. pulex in a river system inhabited by $\boldsymbol{G}$. $d$. celticus will result in a competitive struggle for life, which will end in a victory for $G$. pulex. In this context it is worth while to bear in mind, that in the situations with $0.1 \%$ seawater $10^{\circ} \mathrm{C}$ and with $1 \%$ seawater $5^{\circ} \mathrm{C}$ the mortality rate curves of $G$. pulex and $G . d$. celticus are on an even level, thus giving $G$. pulex in these circumstances an extra advantage. Furthermore, interspecific mating works in the advantage of $G$. pulex at low salinities $(0.1 \%$ and $1 \%$ seawater) and average temperature $\left(10^{\circ} \mathrm{C}\right)$.

Through reproduction of $G . d$. celticus in spring at low temperatures, this competitive pressure can be somewhat slowed down, but certainly not enough to balance the effect of the competition with G. pulex.

- Sutcliffe \& Shaw (1968) are right as to the capability of $G$. $d$. duebeni to invade fresh waters. Even waters with $G$. pulex may be invaded temporarily (van den Beld, 1973). The reason that $G$. $d$. duebeni has not invaded fresh waters on a large scale should not be sought in a decreasing fitness in these waters (see chapter IV and Sutcliffe, 1971), but in differences between $G$. $d$. duebeni and the freshwater species so far as reproduction and viability of the offspring are concerned. In addition sterile interspecific mating may hamper under natural limnic conditions the settlement of $G$. $d$. duebeni populations in inland waters.

- Not only in morphology (Pinkster et al. 1970), but also in an important biotic ecological factor such as competition, differences are demonstrated between $G$. $d$. celticus and $G$. $d$. duebeni. Our results are another argument for a different development and different capabilities of both subspecies. 


\section{ACKNOWLEDGEMENTS}

The author is indebted to Dr. S. Pinkster, curator of the department of Crustacea of the Institute of Taxonomic Zoology (I.T.Z.), Amsterdam, for the facilities he put at his disposal; to Prof. Dr. J. H. Stock for his advices and critical remarks during the experiments and the preparation of this paper; to Dr. K. Schirl, Drs. A. L. Dennert-Distelbrink and Miss M. Engelbrecht of the I.T.Z. for their assistance during the experiments; to $\mathrm{Mr}$. $\mathbf{H}$. Olofsen of the I.T.Z., Drs. R. Potharst, Mr. A. M. B. de Jong, and Mr. L. Wolowitsj of the Mathematical Centre Amsterdam for their statistical advices; to Drs. W. Petersen, Mr. J. Dieleman, Drs. H. Girisch, Mrs. N. Brandse, and Miss M. Maasen of the I.T.Z. for collecting animals in France and Holland; and to Mr. J. Zaagman for his assistance in making the graphs.

\section{LITERATURE}

Beld, F. A. J. VAN DEN, 1973. Cycles annuels de Gammarus duebeni duebeni Liljeborg, 1852 , et de Gammarus pulex pulex (Linné, 1758) le long de la côte française du Boulonnais. Bull. zool. Mus. Univ. Amsterdam, 3 (13) : 79-98.

BovbJeRg, R. V., 1970. Ecological isolation and competitive exclusion in two crayfish (Orconectes virilis and Orconectes immunis). Ecology, 51 : 225-236.

Croghan, P. C., 1961. Competition and mechanisms of osmotic adaptation. Symp. Soc. exp. Biol., 15 : 156167.

Dennert, H. G., A. L. Dennert, P. Kant, S. Pinkster \& J. H. STOCK, 1969. Upstream and downstream migrations in relation to the reproductive cycle and to environmental factors in the amphipod, Gammarus zaddachi. Bijdr. Dierk., 39 : 11-43.

Dennert, H. G. \& M. J. VAN MAREN, 1974. Further observations on the migration of Gammarus zaddachi Sexton (Crustacea, Amphipoda) in a French stream. Bull. zool. Mus. Univ. Amsterdam, 3 (20) : $157-167$.

Gause, G. F., 1932. Experimental studies on the struggle for existence. Mixed populations of two species of yeast. J. exp. Biol., $9: 389-402$.

-, 1934. Experimentelle Untersuchungen über den Kampf ums Dasein zwischen Paramaecium caudatum, Paramaecium aurelia und Stylonychia mytilus. (In Russian). Zool. Zh., 13 : 1-17.

GUENTHER, W. C., 1964. Analysis of variance : i-vii, 1199. (Prentice Hall, Englewood Cliffs, New Jersey).

Hynes, H. B. N., 1954. The ecology of Gammarus duebeni Lilljeborg and its occurrence in fresh water in western Britain. J. anim. Ecol., 23 : 38-84.

,- 1955 . Distribution of some freshwater amphipods in Britain. Verh. int. Verein. theor. angew. Limnol., 12 : $620-628$.

- , 1959. On the occurrence of Gammarus duebeni Lilljeborg in fresh water and of Asellus meridianus Racovitza in western France. Hydrobiologia, 13: 152155.

KINNE, O., 1954. Interspezifische Sterilpaarung als Konkurrenzoecologischer Faktor bei Gammariden (Crustacea, Peracarida). Naturwissenschaften, 18: 434 435.
- , 1963. The effect of temperature and salinity on marine and brackish water animals. I. Temperature. Oceanogr. mar. Biol., 1 : $301-340$.

,- 1964 . The effect of temperature and salinity on marine and brackish water animals. II. Salinity and temperature combinations. Oceanogr. mar. Biol., 2 : $281-339$.

LESLIE, P. H., 1957. An analysis of the data for some experiments carried out by Gause with populations of the Protozoa Paramaecium aurelia and Paramaecium caudatum. Biometrika, $44: 314-327$.

,- 1962 . A stochastic model for two competing species of Tribolium and its application to some experimental data. Biometrika, $49: 1-25$.

Lesle, P. H. \& J. C. Gower, 1958. The properties of a stochastic model for two competing species. Biometrika, 45 : 316-330.

- \& -, 1960. The properties of a stochastic model for the predator-prey type of interaction between two species. Biometrika, 47 : 219-234.

Lockwood, A. P. M., 1961. The urine of Gammarus duebeni and Gammarus pulex. J. exp. Biol., 38 : $647-658$.

LotkA, A. J., 1932. The growth of mixed populations, two species competing for a common food supply. J. Wash. Acad. Sci., 22 : 461-469.

MAYR, E., E. G. LINSLeY \& R. L. Usinger, 1953. Methods and principles of systematic zoology: $\mathrm{i}-\mathrm{ix}$, 1-328. (McGraw-Hill, New York, Toronto, London).

MiLler, R. S., 1967. Pattern and process in competition. Adv. ecol. Res., 4 : $1-74$.

Milne, A., 1961. Definition of competition among animals. Symp. Soc. exp. Biol., $15: 40-61$.

Neyman, J., T. Park \& E. L. ScotT, 1956. Struggle for existence. The Tribolium model: biological and statistical aspects. Proc. Third Berkeley Symp. on Math. Statist. and Prob., $4: 41-79$. (Univ. California Press, Berkeley, Los Angeles, London).

OduM, E. P., 1971. Fundamentals of ecology (3rd ed.): i-xiv, 1-574. (Saunders, Philadelphia).

Pacaud, A., 1952. Nouvelle revue de la distribution géographique des Gammares dans les eaux continentales françaises. C: r. somm. Séanc. Soc. Biogéogr., 252-253 : 95-111.

PArK, T., 1954. Experimental studies of interspecies competition. II. Temperature, humidity and competition in two species of Tribolium. Physiol. Zool., 27 : 177-238.

-, 1957. Experimental studies of interspecies competition. III. Relation of initial species proportion to competitive outcome in populations of Tribolium. Physiol. Zool., 30 : $22-40$.

PARK, T. \& M. LlOYD, 1955. Natural selection and the outcome of competition. Am. Nat., 89: 235-240.

PinSTER, S., 1972. On members of the Gammarus pulexgroup (Crustacea-Amphipoda) from western Europe. Bijdr. Dierk., 42 (2) : 164-191.

Pinkster, S., A. L. Dennert, B. Stock \& J. H. Stock, 1970. The problem of European freshwater populations of Gammarus duebeni Liljeborg, 1852. Bijdr. Dierk., 40 (2): 116-147.

REID, D. M., 1939. On the occurrence of Gammarus duebeni (Lillj.) (Crustacea, Amphipoda) in Ireland. Proc. R. Ir. Acad., (B) 45 : 207-214. 
Rescigno, A. \& I. W. RichaRdson, 1965. On the competitive exclusion principle. Bull. Math. Biophys., 27 : $85-89$.

- \& -, 1967. The struggle for life: I. Two species. Bull. Math. Biophys., 29 : 377-388.

Stock, J. H. \& S. Pinkster, 1970. Irish and French freshwater populations of Gammarus duebeni subspecifically different from brackish water populations. Nature, Lond., 228 : 874-875.

SuTClifFE, D. W., 1967. A reexamination of observations on the distribution of Gammarus duebeni Lilljeborg in relation to the salt content in fresh water. J. anim. Ecol., 36 : 579-597.

,- 1968 . Sodium regulation and adaptation to fresh water in gammarid Crustaceans. J. exp. Biol., 48 : 359-380.

-, 1970. Experimental populations of Gammarus duebeni in fresh water with a low sodium content. Nature, Lond., 228 : 875-876.
-, 1971. Sodium influx and loss in freshwater and brackish water populations of the amphipod Gammarus duebeni Lilljeborg. J. exp. Biol., 54 : 255-268.

- , 1972. An examination of subspecific differences in the merus of the fifth walking leg of the amphipod Gammarus duebeni Lilljeborg. Freshwat. Biol., 2 : 203-216.

SuTClifFE, D. W. \& J. Shaw, 1968. Sodium regulation in the amphipod Gammarus duebeni Lilljeborg from freshwater localities in Ireland. J. exp. Biol., 48 : $339-358$.

VolterRA, V., 1931. Leçons sur la théorie mathématique de la lutte pour la vie: $i-v i, 1-214$. (Gauthier-Villars, Paris).

Weber, R. E. \& D. H. SpaArgaren, 1970. On the influence of temperature on the osmoregulation of Crangon crangon and its significance under esturarine conditions. Neth. J. Sea Res., 5 (1) : 108-120.

Received : 12 November 1973 